\title{
LA DESPEDIDA, MODERNO SUBGÉNERO DE LA ELEGÍA
}

\section{Paz Díez-Taboada}

\section{Centro Asociado a la UNED de Madrid}

En épocas relativamente recientes ha sido discutida e, incluso, negada la existencia de los géneros literarios y, también, su validez instrumental para el estudio de la literatura, sin embargo, nadie duda hoy de ellas ni de que el estudio deductivo de una serie literaria como constituyente de un género o subgénero, es cuestión de capital importancia en la orientación actual de los estudios literarios, tanto teóricos como históricos. Por géneros literarios entendemos las variedades o especificidades pertenecientes a cada una de las tres categorías generalizadoras de la taxonomía literaria, o sea, a la lírica, la épica o narrativa y la dramática (Kayser, 1972: 438-445). La crítica considera que pertenecen a alguna de estas categorías aquellas obras que, en conjunto, presentan un haz de rasgos estilísticos, estructurales y temáticos comunes, o sea, particularidades semejantes de invención, disposición y elocución ${ }^{~}$.

1 «El género debe entenderse como agrupación de obras literarias, basada tanto en la forma exterior (metro o estructura específicos) como en la interior (actitud, tono, propósito; dicho más toscamente: tema y público)» (Wellek y Warren, 1959²: 278). 
Por otra parte, «la categoría de género es, en principio, relativa, histórica, tradicional y empírica. Es un trabajar provisional de la mente crítica sobre una serie de datos históricos individuales que se repiten, en algunos de sus aspectos por lo menos, y que el crítico trata de tipificar» (Díez Taboada, 1964: 13). Según esto, la determinación de una serie literaria como constitutiva de un género o subgénero que no haya sido considerado tradicionalmente como tal, debe establecerse sobre la relación que dichas obras guardan entre sí, en cuanto que presentan unos determinados rasgos comunes que genéricamente las definen.

Además, un género no ha existido siempre ni universalmente, sino que ha llegado a serlo en un determinado período histórico-literario, porque «un nuevo género es siempre la transformación de uno o de varios géneros antiguos: por inversión, por desplazamiento, por combinación» (Todorov, 1988: 34). Surgidos en épocas lejanas y habiendo tenido múltiples tipos y variantes en su larga historia, unos existen aún en nuestros días, como la tragedia, la comedia o la misma elegía; aunque otros, como la epopeya, el épodo o el poema épico, han desaparecido; algunos han surgido en épocas modernas (la novela, tal como hoy se entiende, o el sainete y el vaudeville) y, sin duda, otros nuevos están gestándose.

Los temas y estructuras que, implícitos o explícitos, latentes o expresos, se encuentran en obras precedentes, tras lentos y complejos procesos de re-literaturización, se decantan en nuevas obras que, si en parte enlazan con las anteriores y las continúan, al mismo tiempo, divergen de ellas hasta tal punto que bien pueden considerarse como iniciadoras de géneros o subgéneros distintos. Por tanto, un género no surge ex nihilo, sino que se nutre de la propia tradición literaria, que no es la inmovilidad de la repetición mimética o la vuelta al pasado, sino, bien al contrario, la necesaria retroalimentación que posibilita las nuevas creaciones.

Por último, puesto que «los géneros son una realidad histórica..., sólo podemos conocerla y comprenderla según va sucediendo» (Díez Taboada, 1964: 13), o sea, en su propio devenir. Por tanto, el estudio de una serie como supuesto género o subgénero literario ha de basarse en la observación de la praxis poético-literaria que los autores hayan puesto en juego, procediendo por imitación y diversificación, por decodificación y codificación, a partir de obras literarias precedentes; pues, por supuesto, antes que creador, el poeta ha sido lector de obras anteriormente creadas $\mathrm{y}$, sobre todo, receptor de una determinada tradición literaria. 
Si aceptamos que la Elegía es un género lírico históricamente constituido, con diversos tipos y modalidades en su larga y rica tradición -y sin solución de continuidad hasta la fecha-, también podemos establecer que, en una determinada época de su devenir histórico, una de sus variantes, la Despedida, se constituyó en un subgénero o especificidad poética de dicho género, con invención (argumenta e imaginario), disposición (estructura) y elocución (retórica o estilística) propias.

\section{LA ELEGÍA}

Heredera de sus homónimas griega y latina, la elegía, tal y como modernamente se concibe, no es coincidente totalmente con ellas ni en su temática y estilo ni, desde luego, en su métrica —el dístico elegíaco, imitado en las lenguas modernas por la combinación de endecasílabos y heptasílabos o sólo por los primeros, en tercetos encadenados-. De origen griego ${ }^{2}$, el término fue recuperado en el Renacimiento para denominar el género al que pertenecían poemas de tema más o menos relacionado con el de las elegías de la antigüedad clásica; o sea, que poseían una amplia temática digresiva, pero siempre centrados en la consideración meditativa o reflexiva del valor de las cosas humanas: el amor, la amistad, el paso del tiempo, la condición mortal del hombre y, sobre todo, la inexorabilidad de la muerte ${ }^{3}$.

2 «La métrica de la Elegía, basada en el dístico llamado elegíaco --un hexámetro y un pentámetro - [...] Cada hexámetro iba seguido de un epifonema formado por la fusión de dos elementos dactílicos catalécticos: al relato o exposición del cantor, seguía el lamento del coro [...] El acompañamiento musical de la flauta, que entra en Grecia, procedente de Asia, en el siglo VII a.C., favorece la formación de este tipo de estrofa. Pero quizás no deba limitarse el origen de la elegía al canto de duelo en el banquete fúnebre, pues parece haber relación entre ella y cultos como el de Demeter y, de otra parte, la palabra élegos, seguramente no griega, tiene relación con glosas que designan simplemente el estado de locura que los griegos consideraban consustancial con la creación poética» (Rodríguez Adrados, 1956: XIV-XV).

3 «Del elogio del muerto pueden derivarse fácilmente la parénesis y las consideraciones morales y las generales sobre la vida [...] La Elegía es por antonomasia la poesía de la exhortación y la reflexión sobre los temas más diversos: militares, políticos, morales, sobre el sentido de la vida humana, etc. No faltan tampoco los himnos a los dioses, los temas autobiográficos ni [...] la narración» (Rodríguez Adrados, 1956: XIV y XVI). «Los temas que nos parecen la materia misma de la elegía, audacias y temores de los amantes, aspiración a la naturaleza bucólica, la enfermedad, la separación y la muerte, los arrebatos y la desesperación eran cultivados indiferentemente en toda clase de metros, algunos tan complicados y denotando un virtuosismo tal que parecían una caricatura de la pasión sincera» (Bayet, 1966: 281; cursivas nuestras en éste y demás casos). 
De lo dicho se infiere que, por su doliente elocución, imaginario melancólico y temática generalizadora sobre el dolor de amar, vivir y morir, una elegía es un discurso poético sobre el sentido último de la vida humana o, más precisamente, la consideración del hombre como ser para la muerte. La reflexión sobre su inexorabilidad —en principio, de la ajena, pero ésta es, por supuesto, anuncio e imagen de la propia- lleva al poeta, desde la memoria del ayer al encuentro de un tiempo intemporal y de un lugar utópico donde ubicar al muerto, pero también, por extensión y en ultimidad, al yo propio - autor implícito o voz que habla- en un más allá o estado postmortem.

De manera más o menos explícita, en este movimiento pendular consiste la estructura básica o desarrollo de toda elegía - y, por extensión, de todo poema elegíaco-: del entonces al luego, del ayer perdido a su recuperación en un posible mañana imaginado. Pero, como una vez terminado su tiempo - la edad—, no hay futuro cierto para el hombre, la elegía intenta, por medio de la memoria y de la palabra, transmutar al hombre muerto en palabra viva que, comunicante con todos los demás posibles receptores, haga vivir de nuevo al que murió, lo vivifique de manera sustancialmente distinta, previniendo, así también, la extinción de la voz y del ser del propio poeta. Sin duda, la recuperación de lo perdido se hace virtualmente posible en el topos que es el propio texto poético, con el que se pretende conjurar la azarosa temporalidad por medio de la intemporalidad del arte. El poema, pues, es un sistema de coordenadas en el que se produce la pervivencia de lo perdido: la del hombre muerto en poema vivo $y$, por tanto, también la permanencia de la palabra del propio autor más allá de su existencia efímera.

Todo ello no obstante, la certeza del acabamiento de la humanidad y aun del universo lleva a muchos poetas a no conformarse o consolarse con la transvivificación poemática, ni para el ser querido desaparecido ni aún para ellos mismos. La esperanza en una vida futura -o en cualquier otro tipo de trascendencia - no sólo natural e histórica, sino transhistórica y sobrenatural, auténticamente suprahumana, hace que la mayoría de las elegías cuyos autores pertenecen a un contexto socio-cultural religioso - aunque no siempre pueda comprobarse si realmente poseían creencias de este tipo-, den una salida también religiosa a la cuestión más misteriosa y sin respuesta de todas: la muerte. Todo poema sobre la muerte es un triunfo de la razón sobre la sinrazón, de la palabra sobre el balbuceo y el quejido de dolor por la muerte del ser querido $\mathrm{y}$, además, por la propia muerte. Pero, sobre todo, es un canto de afirmación del vivir humano, en 
general, y de la propia vida: a través del arte, dar cauce al dolor oculto, ordenándolo y estructurándolo, hacer sonar la voz para acallar el grito, gramaticalizar la confusión, poner de relieve y afirmar el propio yo en el arte, expresando el anonadamiento y el estupor que la muerte causa $\mathrm{y}$, también, la nostalgia del feliz tiempo pasado y la melancolía del vivir.

\section{Tipos de elegía}

A lo largo de la historia de la literatura, la elegía ha recibido distintas denominaciones, según que los poemas llorasen la muerte de un ser querido o, en general, lamentaran lo pasado y ya perdido: el amor roto u olvidado (la separación de los amantes o la ruptura), el paso del tiempo (infancia o juventud), la partida de la patria o el destierro, etc. Así, el género elegía ha recibido, desde el Renacimiento y en toda Europa, distintas denominaciones, cultas unas, populares otras, según qué objeto se lamentara y de qué forma: planto, trenos, nehemías, epicedio, endechas, etc.

En sus Anotaciones a la obra de Garcilaso, Fernando de Herrera (1973: 290 y 291) analiza los modelos de la elegía clásica — de Tibulo, Propercio y Ovidio, entre otros-y, siguiendo a Scalígero, dice que «llamáronse versos élegos, de la conmiseración de los amantes» y distingue cuatro temas principales: amoroso, funeral, histórico y de circunstancias. Poco después, López Pinciano (1953: 293-294) se refería a la diversidad de nombres y a la amplia variedad de temas que trataba la elegía:

«Los [poemas] que se hazían a partidas y tornadas de amigos eran assimismo muchos, porque según a lo que yuan los ausentes, y las tierras y las marcas que auían de passar y otras cosas, assí les dauan los nombres. Los Élegos y miserables poemas fueron también no pocos, porque los que se hazían a suuersiones de patrias, llamaban Threnos o lamentaciones; los que a muerte, fueron dichos primero Elegías, mas ya este nombre de especie de tristeza se hizo género, y significa todo poema lutuoso y triste, como son lo que en Castilla decimos Endechas (házense a destierros, absencias, disfauores de amor y golpes de fortuna), y los poemas que a muerte se aplican, han tomado otro nombre, dicho Epicedio». 
Modernamente se distinguen tres tipos básicos o variantes principales de la elegía ${ }^{4}$. En primer lugar, la funeral -el clásico epicedio- es un poema que lamenta la muerte, pero no en general, sino una muerte concreta $\mathrm{y}$, con frecuencia aunque no siempre, real; por tanto, está dedicado e, incluso, apelativamente dirigido a un muerto. Muy abundante en todas las épocas, ha tenido en nuestra literatura testimonios de muy alta calidad poética. Desde el «Planto por Trotaconventos» del supuesto Arcipreste de Hita, hasta la «Elegía» (segunda a la muerte de Ramón Sijé) de Miguel Hernández, pasando por las «Coplas a la muerte del maestre don Rodrigo» de Jorge Manrique, la «Canción a la muerte de Carlos Félix» de Lope de Vega, el «Canto a Teresa» de Espronceda o el «Llanto por Ignacio Sánchez Mejías» de García Lorca, la literatura española cuenta con impresionantes monumentos poéticos en la expresión del supremo dolor. Real o ficticia, la muerte de un ser querido es el presupuesto intratextual y asunto de la composición; y el dolor que esta muerte causa y que el texto glosa, pertenece al ámbito íntimo del yo poético, que suele ser identificable con el propio autor.

En segundo término, la heroica lamenta la muerte de una persona de relieve nacional que, por sus hechos en vida o por las circunstancias de su muerte, ha merecido el reconocimiento popular (guerreros, revolucionarios, políticos, etc.). El presupuesto intratextual es también una muerte, pero la que afecta, en mayor o menor medida, a un amplio grupo humano o a toda la sociedad. Una variante moderna puede considerarse la de amistad o circunstancias, que parte de reales o supuestos afecto y/o admiración que el autor sentía por alguna persona fallecida de cuya amistad gozó; aunque, también, por ciertas figuras públicas e influyentes desaparecidas a las que en el poema se rinde homenaje. La relación entre ambas es hoy tan estrecha que resulta difícil distinguirlas y no suele quedar claro, ni intra ni extratextualmente, si el fallecido y el autor mantuvieron en vida lazos de amistad, ni tampoco si aquél era tan querido y admirado por éste como del texto se infiere; por lo que parece que el presupuesto - tan fáctico como táctico- de estas elegías es, con frecuencia, un oportunista aprovechamiento de la ocasión; o sea, el afán del autor por adquirir notoriedad y fama o, por lo menos, bienquistarse con amigos y deudos del fallecido, como es el caso de tantas dedicadas a la muerte de reyes, nobles, políticos y poderosos de toda laya y condición.

4 Sobre la elegía española, en general, vid. Wardropper (1968: 7-27) y Camacho Guizado (1969); sobre la renacentista y barroca, López Bueno (ed., 1996); y sobre la romántica, Díez Taboada (1977: 13-79). 
Por último, la patriótica o política, antiguamente denominada trenos, aunque, a veces, se identifique con la heroica, sin embargo, no es un mismo tipo de poema, pues en ella se lamenta una desgracia o catástrofe colectiva que afecta a todo un pueblo o a un amplio grupo humano: guerras, matanzas, invasiones, destierros, etc.; $y$, por tanto, parten de un distinto supuesto poético, ya que no es la muerte -0 , por lo menos, no siempre lo es- lo que provoca la vivencia de dolor que el poema expone.

Aunque el supuesto intratextual de los tipos citados es, en general, la muerte, sin embargo, también son auténticas elegías $-\mathrm{y}$, como hemos visto por la cita de El Pinciano, así fueron consideradas en otro tiempo- ciertos poemas cuyos supuestos poéticos determinantes no son ni la muerte ni la desgracia colectiva, sino, por ejemplo, la separación y distancia de alguien o algo querido cuya pérdida lamenta un yo o sujeto poético. Éstos son los llamados poemas de ausencia -o, simplemente, ausencias- y las despedidas.

En los primeros, el yo poético se encuentra ausente - separado y distante, aunque no siempre definitivamente- de la persona de cuya presencia gozó en otro tiempo o de la tierra natal o querida, de los que siente nostalgia y añoranza; por lo que, en general, el poema expresa el deseo del retorno del ser querido o del propio yo al encuentro de lo perdido. En cuanto a las segundas, el poema expone el dolor por la separación del objeto amado, pero contemplada ésta en su inicio, desde la memoria o desde el presente intemporal del poema: el yo poético ausente o en previsión de la ausencia, dice adiós lastimosa y patéticamente al tú querido del que ya se halla distante, a aquél que está a punto de abandonar o al que le abandona.

Esquema I

\section{LA ELEGÍA}

\begin{tabular}{lll}
\hline Presupuesto intratextual & Repercusión & Tipos \\
\hline 1. Muerte & Privada o Pública & FUNERAL \\
2. Muerte o Pérdida & Pública & HEROICA \\
3. Desgracia o Catástrofe & Pública & PATRIÓTICA O POLÍTICA \\
4. Distancia & Privada & AUSENCIA \\
5. Separación en su inicio & Privada o Pública & DESPEDIDA O ADIÓS \\
\hline
\end{tabular}




\section{LA DESPEDIDA}

Según el Diccionario de la RAE (198420: 482), el significado del sustantivo femenino despedida es, en su primera acepción, «acción y efecto de despedirse» ${ }^{5}$; y el de esta forma pronominal del antedicho verbo dicendi, del que deriva el sustantivo en cuestión, es «hacer o decir alguna expresión de afecto o cortesanía para separarse una persona de otra $u$ otras». Por tanto y en principio, una despedida es un acto lingüístico-ilocutivo ${ }^{6}$ que consiste en una expresión de ruptura del contacto comunicativo, como son las diversas fórmulas para dar por terminada una conversación o finalizar una carta: adiós ${ }^{7}$, hasta pronto, hasta luego, hasta la vista, etc.

Además, es también el acto verbal con que se formaliza la interrupción o ruptura del contacto amoroso, amistoso, profesional, etc. entre dos personas y, por extensión, entre una persona y algo amado o poseído, que ya se ha perdido o está en trance de perderse; todo lo cual presupone la existencia real y extralingüística de algún tipo de distancia o separación entre quien se despide y aquél o aquello de lo que se despide. Así, pues, considerada linguiísticamente, la despedida es la verbalización ilocutiva y fática de una separación socialmente ritualizada.

Desde las literaturas grecolatina y bíblica a la nuestra - tanto popular como culta- $-y$, sobre todo, desde el último cuarto del siglo XVIII hasta nuestros días, el acto linguiístico y comunicativo de la despedida ha llegado a constituirse en un subgénero de la elegía, tras el consiguiente largo y complejo proceso de literaturización y poetización. Una serie de poemas que dicen adiós presentan rasgos comunes de invención (temática e imaginario) y de elocución (topoi y métrica) que revelan la progresiva constitución de la despedida como subgénero específico de lo que, tradicionalmente, se consideraba una variante temática de la elegía.

5 Segunda acepción: «En ciertos cantos populares, la copla final en que el cantor se despide»; por tanto, el término ya está lexicalizado con rango literario como denominación de un elemento estructural del cantar popular, aunque de creación y transmisión oral y no perteneciente a la lírica culta.

6 También ilocutorio o ilocucionario, según traducciones de la conocida denominación de Austin (Domínguez Caparrós, 1986: 83-121).

7 La grafía moderna del término manifiesta la definitiva lexicalización de a Dios, circunstancial de lugar a dónde, usado con intransitivos de permanencia y movimiento, como el de compañía con Dios -también con atributivos-: quédate o voyme a Dios y quédese, sea o vaya ud. con Dios; ambas eran habituales y generalizadas fórmulas de despedida. 
El primer rasgo que define a la despedida como subgénero de la elegía es el ser lírica con asunto; y en esto también coincide con los poemas de ausencia, aunque, por supuesto, de distinto asunto. Ambos tipos de poemas parten de un mismo presupuesto poético ficcional: la separación intratextual y explícitamente enunciada como imperativa e inexorable, entre los dos primeros personajes inmanentes de la ficción poética: el yo o voz que se despide y el tú al que el primero se dirige ${ }^{8}$. Y este segundo rasgo, el de texto explícitamente apelativo - también común con la elegía, pero no siempre con la ausencia-, es básico y definitorio de la despedida. En cuanto al tema principal, es el dolor y desgarro sentimental que produce dicha separación o distancia; sea ésta debida a la marcha o viaje del propio yo, del tú poético o, incluso, de un tercer personaje.

Por último, en la despedida se articulan diversos motivos que glosan las varias circunstancias de la separación y las distintas vivencias de los personajes ante ella — sobre todo, las del yo-. Habitualmente, la dispositio poemática se inicia con el anuncio explícito de dicha separación, seguido de la ponderación de su inexorabilidad, a lo que precede o sigue la verbalización del adiós. Por lo general, se observa un desarrollo pendular entre la rememoración del feliz tiempo pasado y el lamento por lo ya perdido o a punto de perderse, con la consiguiente magnificación del dolor por la ausencia en que el yo vive o prevé que va a vivir; en cuyo caso, el lamento se amplifica con la exposición de los malos augurios y temores que asaltan la imaginación del yo poético.

\section{Los presupuestos intratextuales de la ficción poética de despedida}

Como hemos apuntado, la despedida se origina intratextualmente a partir de una supuesta separación entre los dos principales personajes inmanentes, habitualmente coincidentes con los protagonistas de la ficción poética; y el carácter de dicha separación determina los cinco principales tipos de despedida. Así, la separación física y espacial da origen a la partida, la sentimental — también la ideológica- a la ruptura y ambas pueden ser amorosas — separación de los amantes-o

8 Para la determinación genérica o subgenérica, es indiferente, claro está, si la separación fue realmente vivida y sentida por el autor o si es solamente presupuesto intratextual de la ficción poética. 
afectivas; pero, claro está, a ésta última le precede o sigue una situación de distanciamiento espacial o partida de uno de los dos protagonistas de la ficción - con frecuencia, la del yo poético-. El adiós suele estar dirigido al tú - singular, plural o colectivo- que se va o al que es abandonado: amada, amante, familiar, amigo o personaje célebre; también, a seres y elementos naturales: aves, flores, árboles, fuentes, ríos, mar, etc.; pero, sobre todo, a lugares como la tierra natal, ciudad o región particularmente queridas, cuya denominación genérica es metonimia de lo que realmente se despide el yo poético, del tú generalizado de quienes en ellas habitan.

De ambos presupuestos parten los llamados cantos del destierro -que parece mejor denominar llantos-, pues, en general, es la ruptura ideológica, política y/o social con la Patria lo que hace del yo un proscrito, condenado a la inexcusable partida al destierro y a los consiguientes alejamiento y ausencia de sus seres queridos y de su hábitat y acostumbrado modo de vida. No obstante, en algún caso no existe tal proscripción ni condena y el discurso poético se genera desde una vivencia de pérdida de la patria, a causa de una ruptura ideológica con la realidad político-social, lo que conduce al yo poético a una situación de exilio interior ${ }^{9}$.

Por tanto, la separación no es sólo espacial, sino que también puede ser existencial - con frecuencia, metaforizada como partida-, debida al paso del tiempo o trascurso del vivir, cuyas contingencias el hombre siente como pérdidas, lo que origina la lamentación por su fugacidad. Así, el yo propio - es lo habitual - se despide de un tú impropio personificado, que puede ser la edad u otro período de tiempo ${ }^{10}$; también las vivencias y potencias de los felices tiempos ya pasados, como en los adioses al amor y los muy románticos a las ilusiones y ensue$\tilde{n}{ }^{11}$. De este tipo es la serie característica de los metapoéticos adioses a la poesía —de inconfundible raigambre clásica-, simbolizada

9 Por ej., en «A los Poetas» (1853) de Vicente Barrantes: el yo poético expresa su dolor ante las tristes circunstancias socio-políticas de España.

10 Por ej., «Despedida de la Juventud» (1802) de Quintana, fragmento inicial del Canto III («Cuán fugaces los años...», vs. 1852-1920) de El Diablo Mundo (1841) de Espronceda, «A los treinta años» (1848) de Álvarez de Unzueta, «Despedida del Año de 1843» [sic, pero 1842] de Coronado o "Adiós a las Noches de Verano» (1850) de Cabrera.

11 Además del citado fragmento de El Diablo Mundo de Espronceda, el soneto «Adiós, dulce ilusión rica en colores...» (1841) de Álvarez de Unzueta, «Recuerdos» (1842) de García Gutiérrez, "La Confesión» (1842) de Campoamor, el Canto XIII de Horas Perdidas (1844) de Eduardo Asquerino, «Introducción» (El Estío, 1850) de Selgas, el cantar «Esperanza de mi vida...» (CXVI de La Soledad, 1861) de Ferrán, etc. 
ésta tópicamente por las Musas o la lira; aunque, a partir del Romanticismo, también a veces por el arpa ossiánica o el laúd trovadoresco ${ }^{12}$.

Por otra parte, la pérdida que se glosa y lamenta puede ser la aún no sucedida de la propia vida, si el yo poético se siente o finge en trance de perderla, como es el caso de tantos adioses a la vida ${ }^{13}$, que de melólogos y melodramas metastasianos pasaron a novelas sentimentales - sobre todo, a las epistolares, tan lacrimógenas-, a la poesía y, por supuesto, invadieron la ópera decimonónica. Y, por último, del presupuesto de la separación total o absoluta, o sea, de la muerte real o ficticia de un tú poético, parte la despedida funeral, modalidad elocutiva de algunas elegías que se formulan desde el ahora del presente textual como adiós definitivo a quien, aunque ya muerto - por tanto, ser inanimado que no puede responder-, el yo poético se dirige desde su propia memoria, en donde aquél permanece ${ }^{14}$.

\section{La despedida, desde la memoria y desde el presente textual}

Todos los presupuestos antedichos pueden estar considerados desde la memoria del yo poético; en cuyo caso, el supuesto fatal instante en

12 El pasaje final de «Elegía» (cuarta de las dedicadas a Olimpia; 1820) de Rivas, la famosa «A las Musas. Elegía» (h. 1821) de Leandro Fernández de Moratín, el soneto «iMuerto está el corazón: ni aun el suspiro...» (1849) de Dacarrete, «Adiós a la Lira. Imitación de Lamartine» (1850) de Gómez de Avellaneda, «Adiós a la Melancolía» (1857) de Arnao, «A la Lira» (1858) de Zea, etc.

${ }_{13}$ La carta de doña Elvira a don Félix de Montemar de «El Estudiante de Salamanca» («Voy a morir; perdona si mi acento...», vs. 371-418; 1840) de Espronceda, el fragmento "Adiós, tierra infeliz, triste y esclava..." de "Armonía Religiosa» (1842) de Arolas, el Canto XVII de Horas Perdidas (1844) de Asquerino, «Corona de Muerte» (1849) de Arnao, «La Voz del Cielo. Imitación de Uhland» (1849) de Cabrera, la conocida çarta de «El Tren Expreso» (Canto III: «El Crepúsculo», II; 1872) de Campoamor, etc. Éste, además, parodió los adioses a la vida en «Don Juan» (1872), en la cínica carta-circular que el seductor, ya viejo, les envía a sus antiguas amadas para moverlas a compasión (Canto I: «Deja (aquí el nombre) que en mi triste estancia...»).

14 «A la memoria desgraciada del joven literato don Mariano José de Larra» (1837) de Zorrilla, «A la Muerte de Espronceda» (1842) de Gil y Carrasco, «El Sepulcro de Evarina. (Imitación de Ossián)» (1842) de García Gutiérrez, «En la Tumba de don Enrique Gil» (h. 1848) de Vera e Isla, «Elegía. A Carlos Latorre» (p. 1851) de Fernández y González, el fragmento de ls «Epístola a Pedro» («Bien te dice mi voz que soy tu hermano...», vs. $145-185 ; 1856$ ) de E.F. Sanz, dirigido al fallecido Gil y Carrasco, el cantar «Madre mía, compañera...» (XXXV de La Soledad, 1861) de Ferrán, «Una Lágrima a su Memoria» (1847), «El Entierro de la Niña» (1849), «La Niña Muerta» y «Ultimo Adiós» (ambas, h. 1868) de Arnao, etc. 
que se inicia la separación y el consiguiente acto de despedida pertenecen al pasado intratextual. El motivo central es, pues, la rememoración de dicho triste momento: las circunstancias en que se produjo, el aspecto físico, sentimientos y manifestaciones de dolor del yo y del tú poéticos y, sobre todo, el adiós -implícito o explícito- que en aquella ocasión supuestamente se dijo o se dijeron ambos protagonistas; a todo lo cual suele seguir la rememoración del feliz ayer, anterior a la separación, en contraste con la tristemente presente situación de ausencia.

La separación se contempla, pues, en su ya pasado inicio, en los momentos inmediatamente anteriores, cuando el yo poético preveía dicha separación, o en los posteriores a ella. En estos casos, predomina el planteamiento lírico-narrativo, pues, en general, el yo poético es la voz que, en flash-back o vuelta atrás, describe y narra lo sucedido, introduce pasajes dialógicos, haciendo oír las voces del yo y el tú protagonistas, de los testigos del feliz ayer y/o de la triste separación; e, incluso, personificándolos, también hablan objetos inanimados relacionados con los sucesos que se rememoran.

En las últimas épocas histórico-literarias, tras el auge romántico, la despedida se centra, progresivamente y casi con exclusividad, en el anuncio de la separación, intratextualmente inminente, y en la enunciación explícita del adiós; ceden los planteamientos narrativos y se adelgaza la glosa de las circunstancias de partida o ruptura; se amplifica, en cambio, la magnificación del llanto por la separación del ser querido, al que se le hacen y del que se requieren promesas de amor y de amistad y al que se le encarece el recuerdo. El poema deriva, pues, hacia el lamento por lo perdido o lo que se está en trance de perder, por la prevista situación de ausencia y la incertidumbre del futuro y, sobre todo, por el desamparo y soledad del yo en el mundo.

En conclusión, con uno u otro enfoque, el carácter definitorio de la despedida, en cuanto que poema elegíaco, es que tematiza la instantaneidad misma de la separación como presupuesto de la expresión literaturizada y líricamente poetizada del adiós; y no, como en la elegía sensu stricto, el hecho luctuoso ya sucedido o, como en las ausencias, sólo lo ya perdido. Por tanto, la despedida no sólo es el más moderno de los subgéneros elegíacos por su génesis cronológica, sino también porque es el discurso poético de la instantaneidad, pues contempla la separación en su arranque, tratando de expresar el dolor existencial de la pérdida en el instante mismo en que se produce. Así, pues, el adiós que en el poema se enuncia es la fórmula que confirma y ritualiza la vivencia de la separación y la distancia espa- 
cial, sentimental, ideológica, temporal o absoluta - la muerteentre el yo poético y el tú del que se despide; o sea, el desgarro existencial que es el vivir.

\section{La comunicación intratextual de la despedida}

Un poema de despedida es, en primer lugar y como cualquier otro texto, un hecho lingüístico, significativo y comunicativo; por tanto, mensaje intencional y explícitamente apelativo de un emisor a un receptor. Por su carácter literario, éstos son, en principio, el autor y el destinatario o lector, implícitos ambos en el propio mensaje o texto ${ }^{15}$; pero, además, intratextualmente explícitos, se distinguen: 1) un yo poético o voz que habla; 2) un tú poético, al que el primero se dirige, y 3 ) aquél de quien se habla, o sea, el héroe, en palabras de OkopienSlawinska (1979: 606) ${ }^{16}$, que, como es normal en un poema lírico, suele ser el propio yo poético, pero también el tú; y tanto éste (vivo o ya muerto) como aquél, humanos; aunque también no humanos, animados o inanimados, y éstos, concretos o abstractos.

Es frecuente que el protagonista de la ficción poética de despedida sea el yo o voz que intratextualmente se despide; pero puede no ser así y darse el caso, aunque sólo sea esporádico, de que el tú poético, al que el discurso del primero se dirige, sea el protagonista que se despide de un tercer personaje; ya que no siempre se parte del presupuesto de que el yo poético sea el que se separa y/o se despide; en estos casos, el yo es, simplemente, el testigo de la separación y despedida de otros dos, de los cuales, lógicamente, por lo menos uno de ellos es siempre el tú poético.

Según Levin (1979: 431-432), el esquema comunicativo intratextual de un poema lírico está determinado por la relación entre la primera y segunda persona del discurso y es condición suficiente para caracterizar-

15 «Le poème lyrique implique toujours la présence de deux personnages: l'auteur implicite et le destinataire. Il est indispensable qu'il y ait une communication entre eux" (Lévine, 1976: 205).

16 «Lo schema fondamentale delle relazioni di persona concentrate nell'opera letteraria, è comune a qualsiasi atto di comunicazione linguistica. A seconda della funzione assolta nei confronti di questo atto, si possono distinguere tre persone che sostengono i ruoli principali: 1) il mittente: colui che parla; 2) el destinatario: colui al quale si parla; 3) l'eroe: colui del quale si parla». 
lo como perteneciente a un género concreto ${ }^{17}$; por tanto, la presencia preponderante de unas pocas relaciones intratextuales en una serie histórica de despedidas, las determina como constituyentes de tal subgénero elegíaco. Comenzando por las más frecuentes, éstas son las principales:

1. a Predominante es la que se establece entre las dos primeras personas del discurso, un yo y un tú propios, o sea, humanos y realmente existentes, susceptibles de ser identificados con el autor real y con una persona - masculina o femenina, singular o plural-, a la que el primero se dirige y con la que, posiblemente, el autor tuvo relación, frecuentemente comprobable ${ }^{18}$ si en el poema aparecen datos, alusiones y referencias que manifiestan que fue realmente dirigido a un destinatario concreto - antes que al lector implícito- o que, por lo menos, fue escrito como epístola o envío poético ${ }^{19}$. Ante este tipo de poemas, el lector real se encuentra en la situación de intruso o tercero excluido en una conversación íntima de la cual es espectador, por sorpresa y sin haber sido llamado (Lévine, 1979: 210). Esporádicamente, el yo propio se identifica con el tú -también propio-hasta tal punto que es la voz de éste, del que el yo se despide, la que se dirige a él; y así, autor y yo poético desaparecen tras el personaje intratextualmente explícito ${ }^{20}$.

2. ${ }^{\text {a }}$ Aunque en menor medida que la anterior, es frecuente la relación intratextual entre un yo y un tú otros, completamente distintos del

17 Levin distingue tres tipos de primera persona en el discurso lírico: propia, «quando l'io esplicito può essere identificato con l'autore reale, o il noi con un ristretto gruppo comprendente l'autore reale»; otra, «quando io non può essere identificato con l'autore reale», y generalizada, «quando noi si riferisce genericamente all'uomo, o all'umanità, o ad un gruppo esteso di persone». En cuanto a la segunda persona, también una propia, «tale da venir identificata con un preciso destinatario reale (singolo o collettivo: interlocutore, uditorio»; impropia, «quando si ha un concreto destinatario de la allocuzione, chiaramente impossibilitato a raccoglierla»; generalizada, «quando tu $e$ voi sono genericamente l'uomo, o l'umanità, o una categoria di persone»; $y$, por último, autocomunicativa, «quando $t u=i o$ (allocuzione rivolta a se stesso)».

18 «Il texto è egotico e appellativo; inoltre, il destinatario palese è fisso e rappresenta un personaggio concreto, magari del tutto ignoto al lettore, ma ben noto (e, di regola, prossimo) all'io esplicito» (Levin, 1979: 436).

19 Entre tantas que podrían citarse, la Epístola V, «A González de Candamo», en que Meléndez se despide de este amigo suyo en su partida a Méjico: «¿Huyes, ¡ay!, huyes mis amantes brazos, / dulce Candamo, y entre el indio rudo, / en sus inmensos solitarios bosques / corres a hallar la dicha que en el seno, / en el fiel seno de tu tierno amigo / el cielo y la amistad te guardan sólo?...» (vs. 1-6).

20 En las dos primeras estrofas de «Adiós, España, adiós», Carolina Coronado exhorta a su hermano Pedro, que marchaba a América, a despedirse de España y, en la última, de ella misma: «...y di con triste acento: / jadiós, España, adiós! I ...di ¡Carolina, adiós!» (vs. 7-8 y 24); en la segunda parte, «iAcuérdate de mí!», se despide de su hermano rematando cada estrofa con la frase que le da título y, como antes, dicta y encarece la promesa del recuerdo: «...repite, dulce hermano, / yo me acuerdo de ti. I ...Carolina, / jacuérdate de mí!» (vs. 25-26 y 31-32). 
autor y del receptor implícitos y que apenas pueden ser identificados con ellos porque son explícitos entes de ficción: el yo es una máscara lírica de un monólogo apelativo dirigido a un tú también ficticio; ambos, pues, dramatis persona de una escena, que también puede ser narrativa ${ }^{21}$.

3. ${ }^{\mathrm{a}}$ En tercer lugar, la relación entre un yo propio que se dirige a un tú impropio - no humano pero, por supuesto, personificado-. Unas veces, es un objeto inanimado, concreto o abstracto, pero otras, una entidad natural, sobre todo, de las avaladas por larga tradición poética desde los clásicos; por tanto, el tú puede ser también animado, como algunas aves de valor simbólico ${ }^{22}$. Levin considera que ésta es la relación que se establece en los poemas en los que el yo se despide de una persona muerta; y arguye que ello es así porque lo que caracteriza al tú como impropio —objeto o cosa- es que no tenga posibilidad de respuesta.

Resulta extraña esta inclusión del tú humano muerto en el grupo de las segundas personas objetuales, porque la alocución a un muerto es, sobre todo, una comunicación rememorativa en la que la identidad personal que poseyó el tú al que se habla permanece en la memoria del yo, y aún más vívida ante el silencio que la muerte impone en el presente poético. Además, en el poema funeral, el yo poético no habla propiamente con el muerto, sino al muerto y en su alocución está implícita la certeza de que la persona vive en un estado postmortem; y, si no de manera distinta y misteriosa - lo cual depende de la creencia religiosa del emisor-, por lo menos, sí en el ámbito intemporal de la memoria, tanto del propio yo como del receptor implícito, que quizá haya conocido directamente o por referencias a la persona desaparecida, a la que, en todo caso, el autor pretende darle nueva vida por medio de la palabra poética, y así hacerla perdurar en la memoria histórica.

21 En cuatro de las cinco despedidas de Espronceda, el yo poético es siempre otro explícitamente distinto: «La Entrada del Invierno en Londres» (1828) es un llanto del destierro y despedida de la patria en boca de su amigo Balbino Cortés; en «La Despedida», canto I del ossiánico «Oscar y Malvina» (1827) y «Despedida del Patriota Griego de la Hija del Apóstata» (1834), la separación de los amantes es anunciada por el narrador, un yo distinto, pues, del de los protagonistas de la ficción, que en la primera se despiden en sendos monólogos alternados; y la famosa carta de doña Elvira a don Félix («El Estudiante de Salamanca», 1840) es un lírico adiós al amante y a la vida, perteneciente a la ficción narrativa.

22 En el Romance XIX de Meléndez, «EI Colorín de Filis» (a. 1785), ésta despide a su jilguero, al tiempo de darle la libertad: «« «Ay!», dijo la bella Filis, / y suspiró dulcemente, / «qué mal, jilguerillo, pagas / lo mucho que a mi amor debes!...»» (vs. 29-32). 
Por otra parte, la argumentación sobre la imposibilidad de respuesta del tú poético muerto no parece ser razón suficiente para equipararlo con un tú impersonal -objetual, cosificado-, porque, en definitiva, toda comunicación literaria es en sí misma una comunicación sin respuesta posible: en principio, no la pretende, pero, además, en ningún caso directamente la tiene. Aunque el tú inmanente de un poema haya sido o sea un destinatario real e histórico al que, efectivamente, el autor le haya enviado el poema - cosa que ha ocurrido y ocurre con cierta frecuencia-, la artificiosa textualidad del mensaje literario no es una codificación en primer grado - uso habitual del código lingüístico-, sino en segundo grado $y$, por tanto, siempre comunicación indirecta o supuesto ficticio de tal.

4. ${ }^{\text {a }}$ También la establecida entre un yo propio y un tú generalizado que representa a todo hombre - la humanidad - o a una categoría de personas o grupo humano - familiares, amigos, otros poetas, pueblo, patria, etc.- en el que el yo se siente o sabe integrado, de tal manera que «le vous exclut le je», porque el tú grupal o colectivo incluye al propio yo ${ }^{23}$. Esta relación es la predominante también en algunas partidas de la tierra natal o querida — como en «A Cádiz» de Bermúdez de Castro- $\mathrm{y}$, sobre todo, en los llantos del destierro y despedidas de la patria, en las que el yo propio, ya ausente en el destierro, ya en viaje al exilio o a punto de partir hacia él, se dirige al tú generalizado de la patria, que, por supuesto, es término colectivo que abarca a amada, familiares, amigos e, incluso, a su misma realidad física y/o social ${ }^{24}$. No obstante, algunas despedidas combinan o articulan diversas relaciones intratextuales; así, por ejemplo, en la «Epístola III Heroica de Jovino a sus Amigos de Sevilla», Jovellanos comienza despidiéndose de la ciudad y de su río, el clásico Betis, y se dirige luego a sus amigos sevillanos y, en particular, a Galatea, bajo cuya tópica denominación se esconde una amada desconocida.

23 En «La Despedida» (1898) de Cienfuegos -imitación de la canzonetta «La Partenza» (1746) del Metastasio-, cada octavilla remata, a manera de ritornello, con una pregunta del yo a punto de partir: «¿me olvidará mi amor?, i...habrá una ingrata / que olvide tanto amor?, ... isi, alevosa, / olvidará mi amor?», etc.; excepto las tres últimas, no están dirigidas a Nais - tú amada-, sino a un generalizado vosotros, los conocedores de la ausencia de amor, a los que apostrofa al comienzo de la composición: «Venid, venid, piadosos, / y consolad mi pena, / los que el amor condena / a mi crüel dolor. / Oh vos, que habéis probado / la ausencia un solo instante. / Yo parto y soy amante, / ¿me olvidará mi amor?...» (vs. 1-8).

24 Así en «A la Ausencia» de Moratín: «Prófugo, triste, en mi destino incierto, / dejé mi choza y mis alegres campos / y los muros de Mantua generosa, / y al bienhadado Coridón y Aminta, / y al constante en amor Alfesibeo; / todo lo abandoné. Por ignorada / senda me aparto con errante huella, / y atrás volviendo alguna vez los ojos / adiós, mi patria, sollozando dije; / adiós, praderas verdes...» (vs. 10-19). 
Otras posibles relaciones comunicativas aparecen con menor frecuencia o, incluso, sólo esporádicamente en algunas despedidas. La $5 .^{\mathrm{a}}$, entre un yo propio y un tú con el que, de alguna manera, el primero se identifica; es característica de confidencias, confesiones y notas íntimas, en las que el tú revierte poéticamente sobre el yo que las formula, de tal manera que la segunda persona viene a ser una forma indirecta de la primera, manifestando la autocomunicación característica de todo texto lírico. Se presenta en las despedidas en que el yo rememora la separación sin dirigirse al tú -o al vosotros- del que se ha separado o separa, sino a uno vacío que es el propio yo que contempla y expresa su dolor, esperanza, etc ${ }^{25}$.

Además, en las relaciones señaladas por Levin se echa en falta la que se establece, $6 .^{\mathrm{a}}$, entre un yo propio y un tú otro, o sea, un explícito personaje de ficción. Levin acepta esta relación en la intratextualidad narrativa, pero no en la lírica. Sin embargo, en algunas despedidas, un yo propio, identificable con el autor implícito, se dirige y despide de un tú otro, individual y concreto personaje de ficción, que, a veces, es nombrado explícitamente en el poema, lo que excluye que pueda considerarse impropio o generalizado. A este tú ficticio, convencional y literaturizado, sólo indirectamente puede suponérsele una existencia extratextual y real humana; así en algunas despedidas que siguen determinadas convenciones histórico-literarias -pastoril, mélica, ossiánica-, en las que, por datos y señas que el yo poético da de sí mismo, es fácilmente identificable con el propio autor, aunque el poema esté dirigido a un tú otro.

Desde luego y como hemos apuntado, el carácter ficticio del tú puede ser una forma indirecta de aludir a una persona con la que el autor tuvo realmente relación, revistiendo su discurso de artificiosa literariedad para así alejarlo de la anécdota biográfica concreta, bien porque no quiera exhibirla ante los ojos indiscretos del lector implícito, bien porque pretenda crear un ejercicio poéticamente mostrenco, sin más trascendencia que la de l'art pour l'art; y, por supuesto, también es posible que se haya valido del discurso apelativo como forma de autocomunicación ${ }^{26}$.

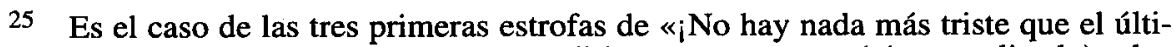
mo adiós!» (1843) de Coronado. El yo se dirige a un vosotros (tú generalizado) a los que comunica su experiencia de dolor en la separación: «Si dos con el alma se amaron en vida / y al fin se separan en vida los dos, / ¿sabéis que es tan grande la pena sentida / que nada hay más triste que el último adiós?...» (vs. 1-12).

26 En el romance «Mi Despedida» (1793) de Mor de Fuentes, el yo que se despide de las tópicas ninfas de nombre bucólico - sobre todo, de Clori-, es identificable con 
7. a En algún caso la voz que habla es la de un yo otro que no se despide de nadie en concreto - tú vacío-, sino que, como es frecuente en la lírica, se produce una autocomunicación explícitamente ficticia en la que se lamenta la separación de alguien o algo querido ${ }^{27}$.

8. ${ }^{a}$ Otras veces, un yo impropio - o sea, no humano y, en algún caso, abstracto- se dirige a un tú propio. Como señala Levin, es una relación muy artificiosa que se encuentra, por ejemplo, en sendos pasajes de dos poemas de Quintana: en «A Elmira», el amor se despide del yo propio y autor implícito, castigándolo así por haber olvidado a su amada de otro tiempo; $y$ «A don Ramón Moreno, sobre el estudio de la poesía» comienza con la voz de las Musas que le recriminan al tú propio su abandono ${ }^{28}$.

9. ${ }^{2}$ Hay también algún ejemplo de comunicación en la que los dos primeros personajes inmanentes se subsumen en un tú generalizado, un nosotros que a todos abarca, como en el citado «A los Poetas» de Barrantes, en que el yo propio —de nuevo, el autor implícito- se dirige, ya desde el título, a dicho grupo al que él mismo pertenece; y, erigiéndose en su portavoz, dice adiós a la pasada gloria y grandeza de España ${ }^{29}$. En este caso, pues, el tú-objeto de despedida no es coincidente con el tú al que explícitamente está dirigido el poema, viniendo a ser, por tanto, un texto autocomunicativo, como decíamos de «La Despedida» de Cienfuegos.

$10{ }^{a}$ Por último, la despedida puede presentarse como discurso no apelativo ni explícitamente recursivo o autocomunicativo, como es común en la lírica. Es el caso de «La Fragata» de Bermúdez de Castro, que, tras el repetido jadiós! del comienzo, pasa a glosar la imagen de una fragata a punto de zarpar; siguiendo a Horacio o a fray Luis de León, el discurso poético es, casi en su totalidad, la narración de la fugaz navegación del débil navío - trasunto simbólico de la vida humana - que, tras haberse adentrado en aguas procelosas, naufraga. En ningún momento hay refe-

el propio autor, pues hace alusión a su marcha a Madrid para labrarse un futuro profesional, y a su autor preferido, Meléndez, al que llama «tierno zagal del Tormes»: «Quedad adiós, dulces ninfas, / a cuyo halago amigable / se inflamó mi escaso numen / desde los mismos umbrales / de la vida... / ¿No fuera aun mejor holgarse / con Filis, Laura o Dorila / en estrechez entrañable, / que lejos de su presencia / ir por siempre a desterrarse?... / Y en tanto, adiós, Clori mía...» (vs. 5-9, 32-36 y 61).

27 Por ej., en «La Partida» (1831) de Estébanez Calderón, la convencional voz femenina de la pastora que lamenta la marcha de su pastor amante y le promete fidelidad: «Ayer, ¡cruda pena!, / mi Tirsis se fue, / llevando a otros prados / su hato a pacer...» (vs. 1-4).

28 «Y decirme: «iAh, cruel! ¿Así te alejas / del tesoro de gracias y de amores / que en ella te ofrecí, y a los dolores / abandonada y sin piedad la dejas?...» (vs. 14-17) y « ¿Y nos dejas, infiel? ¿Y así abandonas / tantas horas de afán? ¿Y así al olvido / la flor darás de tus primeros días, / que tantos lauros a tu sien prometen?...» (vs. 1-4). 
rencia explícita a ninguna de las dos primeras personas del discurso; por tanto, la relación comunicativa es la que se establece, según Levin, entre un yo y un tú vacíos que, en ultimidad, remiten al autor y lector implícitos.

\section{Esquema II}

\section{LA COMUNICACIÓN INTRATEXTUAL DE LA DESPEDIDA}

\section{Relaciones típicas o características, por frecuentes o habituales:}

\section{$1 .^{\mathrm{a}}$ Yo propio $\longrightarrow$ Tú propio $^{30}$ :}
a) Amante
Amada
b) Amada Amante
c) Familiar $\longrightarrow$ Familiar
d) Amigo/-a $\longrightarrow$ Amigo/-a/-s
e) Admirador
$\longrightarrow$ Personalidad relevante

2. ${ }^{a}$ Yo otro $\longrightarrow$ Tú otro (ambos, personajes de ficción) ${ }^{31}$ :
a) Amante
$\rightarrow$ Amada
b) Amada
$\rightarrow$ Amante
c) Familiar
$\rightarrow$ Familiar

3. ${ }^{\mathrm{a}}$ Yo propio $\longrightarrow$ Tú impropio ${ }^{32}:$
a) Natural (animado o inanimado)
b) Espacial (lugar, paraje o recinto)
c) Temporal (edad, año...)
d) Objetual concreto (casa, nave...)
e) Objetual abstracto (amor, ilusiones...)
f) Objetual simbólico (musas, lira...)
g) Persona Muerta

$4^{\text {a }}$ Yo propio $\longrightarrow$ Tú generalizado (por ejemplo, la patria) ${ }^{33}$.

29 «Ay!, ¡adiós, patria!, ¡adiós, gloria!, / ¡pasado que se derrumba...! / ¡adiós todo!... / Cantemos entre rü̈nas...» (vs. 1-3 y 7 ).

30 Ejs.: a) «El Suspiro» (a. 1814) de Meléndez; b) «A él» (h. 1845) de Gómez de Avellaneda; c) «Adiós, España, adiós» (1847) de Coronado; d) «A González de Candamo» (1786 ó 1787) de Meléndez y e) «A la Reina Cristina...» (1840) de Campoamor.

31 Ejs.: a) «La Partida» (1777 6 1779) de Meléndez; b) «Letrilla III» (1818) de Rivas y c) «El Paje Español Pedro Fajardo», I (1842) de Arolas.

32 Ejs.: a) «El Colorín de Filis» (a. 1814) de Meléndez o «La Rosa del Desierto» (a. 1809) de Cienfuegos; b) «Al partir» (1836) de Avellaneda; c) «Despedida de la Juventud» (1802) de Quintana; d) «Despedida de la Cabaña de Antimio» (1820) de Rivas; e) « ¿Adiós, dulce ilusión rica en colores...» (1841) de Miguel de los Santos Alvarez; f) «A las Musas» (h. 1825) de Moratín y g) «A la Memoria de Larra» (1837) de Zorrilla.

33 Ejs.: «La Despedida» (h. 1821) de Moratín, «El Desterrado» y «Oda. Imitación del Salmo Super flumina» (1824) de Rivas, «La Entrada del Invierno en Londres» (1828) de Espronceda y, en general, los llantos del destierro, despedidas de la patria y adioses a la tierra natal. 


\section{Relaciones infrecuentes o esporádicas:}
5. ${ }^{\mathrm{a}} \quad$ Yo propio $\longrightarrow$
Tú otro.
6. ${ }^{\mathrm{a}} \quad$ Yo propio $\longrightarrow$
$\emptyset$ [tú vacío = yo mismo: autocomunicación $]$.
7..$^{\mathrm{a}}$ Yo otro $\longrightarrow$
$\emptyset[$ tú vacío $=$ yo otro: autocom. ficticia].
8. ${ }^{\mathrm{a}} \quad$ Yo impropio $\longrightarrow$
Tú propio.
9. ${ }^{\mathrm{a}} \varnothing[$ yo vacio $] \longrightarrow$
Tú generalizado [ = yo mismo y todos].
$10 .^{\mathrm{a}} \emptyset[$ yo vacío $] \longrightarrow$ $\varnothing[\text { tú vacio }]^{34}$.

\section{La borrosa frontera entre ausencias, partidas y despedidas}

Como hemos apuntado, desde la antigüedad clásica, la elegía venía siendo una especie de cajón de sastre en el que, además del lamento funeral por la muerte de una persona o la reflexiva lamentación - tantas veces denominada oda - por una catástrofe o ante una desdichada situación patriótica o política, se incluían también los poemas que manifestaran, melancólica y patéticamente, los más diversos sentimientos y vivencias del dolor, el luto y la tristeza. Sin embargo, ausencias, partidas y despedidas presentan un asunto concreto y una temática específica: la separación, sea espacial, sentimental —ambas, en los llantos del destierro - y existencial, cuyo grado absoluto es la irreductible separación por la muerte.

Así, la ausencia es una triste situación en la que un yo poético lamenta el encontrarse separado de una persona u objeto querido, o sea, su condición de ausente; y de esto se infieren tres cosas: primera, que dicha supuesta situación ha sido originada por una separación previa; segunda, que el discurso poético es el lamento por la distancia entre el yo poético y el tú cuya presencia se añora y desea; $y$, tercera, que, aunque no siempre, el ausente puede retornar al encuentro de aquél o aquello de cuya compañía o posesión está ausente. En cuanto a la despedida, en un principio, es una derivación de las ausencias, de gran arraigo en la tradición lírica española, tanto popular como culta;

34 Ejs.: 5. ${ }^{\mathrm{a}}$ «Mi Despedida» (1797) de Mor de Fuentes; $6 .^{\mathrm{a}}{ }{ }_{i}$ No hay nada más triste que el último adiós!» (1847) de Coronado; 7. ${ }^{\mathrm{a}}$ «La Partida» (1831) de Estébanez; 8. ${ }^{\mathrm{a}}$ Fragmentos de «A Elmira» $\mathrm{y}$ "A don Ramón Moreno» (1802) de Quintana; 9. " $\mathrm{A}$ los Poetas» (1853) de Barrantes, y 10. ${ }^{\mathrm{a}} \ll$ La Fragata» (1837) de Bermúdez de Castro. 
pues, como ausente del ser amado se expresa la voz lírica en algunas jarchas mozárabes, en bastantes cantigas galaico-portuguesas, en muchas canciones tradicionales y, en general, en la poesía de todas las épocas.

No obstante, desde finales del siglo XVIII, algunos poemas titulados ausencias pueden considerarse ya esbozos de despedida, pues la separación espacial de los dos primeros personajes inmanentes o de algún otro, intratextualmente explícito, se contempla en su inicio o arranque - aunque sea breve y colateralmente - y esto es lo que las diferencia de manera radical de las verdaderas ausencias. Además, la supuesta partida que ha dado origen a la ausencia es explícitamente anunciada, se presenta como imperativa e insoslayable y, como topoi muy destacado, se encuentra la descripción - a veces, muy pormenorizada - de las circunstancias de la marcha o viaje, precedida o seguida de la explícita enunciación del adiós: éste es el caso de algunos de los poemas titulados partidas, tan típicamente dieciochescos, que aún no son despedidas en un sentido estricto o, por lo menos, son sólo una variante de ellas, puesto que no siempre presentan de manera explícita la formulación del adiós, sino, casi exclusivamente, la rememoración de las circunstancias de la separación, la evocación del pasado feliz y, sobre todo, como es normal en un texto lírico, la expresión magnificada del dolor del yo protagonista.

Por otra parte, independientemente del presupuesto desde el que el yo poético se exprese, una ausencia apunta a la irreversible, cualquier partida a la inexorable y toda despedida al último y definitivo adiós a la vida. Por eso, concomitante con la despedida es la elegía funeral en la que la muerte es explícitamente metaforizada en partida y ausencia definitivas y formulada como un adiós a la persona muerta. Y, puesto que el instante de la muerte es visto como el inicio del último viaje al misterioso territorio del Más Allá, es el yo poético el que se presenta a sí mismo patéticamente abandonado y sometido al dolor de ausencia, aunque, por supuesto, el ausente por antonomasia sea el tú muerto, al que, convencionalmente, se le supone gozando de una nueva y feliz existencia.

Desde un punto de vista histórico, pues, la despedida ha sido el resultado de un doble proceso: primero, de derivación y especificación de los poemas de ausencia, pero, en segundo término, de reliteraturización y poetización del acto linguíístico-ilocutivo de despedirse, formalizado en las habituales y ritualizadas fórmulas fáticas. Por todo lo cual bien podría decirse que la Despedida es el poema que, directa o indirectamente, con exclusividad o preferencia, dice adiós. 


\section{Referencias bibliográficas}

BAYET, Jean (1966). Literatura Latina. Barcelona: Ariel.

Camacho Guzado, Antonio. (1969). La Elegía Funeral en la Poesía Española, 9-24 et passim. Madrid: Gredos.

Diccionario de la Lengua Española. I. Madrid: RAE, $1984^{20}$.

DíEZ TOBOADA, Juan María (1964). «Notas sobre un planteamiento moderno de la teoría de los géneros literarios». En Homenajes. Estudios de Filología Española. II, 11-20. Madrid: Graf. Oviedo.

DíEZ TABOADA, María Paz (1977). Introducción a La Elegía Romántica Española, 13-23. Madrid: CSIC.

Domínguez CAPARRós, José (1986). «Literatura y Actos de Lenguaje». En Pragmática de la Comunicación Literaria, ed. José Antonio Mayoral, 83121. Madrid: Arco. Libros.

Herrera, Fernando de (1987). Obras de Garcilaso de la Vega con Anotaciones, ed. Antonio Gallego Morell. Madrid: CSIC [1587].

KAYSER, Wolfgang $\left(1972^{4}\right)$. Interpretación y Análisis de la Obra Literaria, 438-445. Madrid: Gredos [1948].

Levin, Jurij I. (1979). «La Poesia Lirica sotto il Profilo della Comunicazione». En La Semiotica nei Paesi Slavi. Programmi, Problemi, Analisi, ed. Carlo Prevignano, 426-442. Milano: Feltrinelli [1973].

LÉviNE, I.I. (1976). «Le Statut Communicatif du Poème Lyrique». En École de Tartu. Travaux sur les Systèmes de Signes, eds. Y.M. Lotman y B.A. Ouspenski, 205-212. Bruxelles: Complexe.

LÓPEZ BUENO, Begoña (ed.) (1996). La Elegía. III Encuentro Internacional sobre Poesía del Siglo de Oro (Sevilla-Córdoba, 14-17 de noviembre de 1994). Sevilla: Universidad de Sevilla.

LÓPEZ Pinciano, Antonio (1953). Philosophia Antigua Poética. I, ed. Alfredo Carballo Picazo. Madrid: CSIC [1596].

OKOPIEN-SLAwinska, Aleksandra (1967). «Il Sistema dei Personaggi nella Comunicazione Letteraria», Remo Faccani (trad.). En La Semiotica nei Paesi Slavi. Programmi, Problemi, Analisi, ed. Carlo Prevignano, 606619. Milano: Feltrinelli.

RODRíGUEZ AdRADOS, Francisco (1956). Líricos Griegos. Elegíacos y Yambógrafos Arcaicos. I. Barcelona: Alma Mater.

ToDorov, Tzvetan (1988). «El origen de los géneros». En Teoría de los Géneros Literarios, ed. Miguel Ângel Garrido Gallardo, 31-48. Madrid: Arco Libros [1976].

WARDROPPER, Bruce W. (1968). Introducción a Poesía Elegíaca Española, 727. Madrid: Anaya.

WELLEK, Rene, y WARREN, Austin (1959²). Teoría Literaria. Madrid: Gredos. 